"Przegląd Prawa Konstytucyjnego" Nr $4(16) / 2013$

\title{
Sprawozdanie
}

\section{Seminarium naukowe Rozważania nad istotą polityki i polityczności, Rzeszów, 22 kwietnia 2013 r.}

Seminarium nt.: Rozważania nad istota polityki i polityczności zostało zorganizowane przez młodych pracowników Zakładu Teorii Państwa, Prawa i Polityki, kierowanego przez Panią prof. nadzw. dr hab. Sabinę Grabowską i funkcjonującego w ramach Katedry Politologii Uniwersytetu Rzeszowskiego. Pierwsze spotkanie zainaugurowało cykl corocznych seminariów, które w zamierzeniu organizatorów są adresowane do młodych naukowców - politologów oraz prawników - i które ma służyć współpracy naukowców, a także stanowić forum do dzielenia się wynikami badań oraz prowadzenia merytorycznej dyskusji. Do udziału w projekcie zaproszono te osoby, których przedmiot badań dotyczy myśli politycznej, filozofii i teorii polityki, specjalistów badających partie i systemy partyjne, a także tych, którzy prowadzą badania naukowe nad wszystkimi aspektami dotyczącymi polityki rozumianej jako proces zdobywania i utrzymywania władzy politycznej.

Seminarium odbyło się w dniu 22 kwietnia 2013 r. i zgodnie z ideą organizatorów zostało podzielone na trzy sekcje tematyczne. Sekcje nie odbywały się, jak w przypadku licznych konferencji, równolegle, lecz następowały kolejno, z tego powodu uczestnicy mogli być obecni w trakcie wszystkich wystąpień.

Sekcje tematyczne dotyczyły kolejno filozofii polityki i polityczności, funkcjonowania partii politycznych oraz zagadnień o charakterze prawnym i ustrojowym. W seminarium wzięli aktywny udział prelegenci z ośrodków akademickich zlokalizowanych w Poznaniu, Krakowie, Lublinie, Łodzi i Rzeszowie. W dwóch pierwszych sekcjach referaty wygłosiło 8 osób (w każdej z nich zaplanowano 4 wystąpienia), a w ostatniej części głos zabrały dwie 
osoby. Organizatorzy zapowiedzieli, że referaty w formie artykułów naukowych zostaną opublikowane w recenzowanej monografii, która ukaże się w roku bieżącym.

Obrady seminaryjne otworzyła i w ramach sekcji prowadziła reprezentująca organizatorów pani dr Anna Pięta-Szawara. W sekcji pierwszej zaprezentowano cztery wystąpienia, które przybliżały uczestnikom istotę polityki i polityczności w wybranych koncepcjach filozoficznych. Pierwszy z referatów wygłosił mgr Piotr Gugała z Uniwersytetu Jagiellońskiego w Krakowie, przedstawiając zgromadzonym zarys poglądów Bronisława Ferdynanda Trentowskiego i jego rozumienie polityki. Referent wyjaśnił sens pojęcia „polityka” oraz „cybernetyka”, które Trentowski rozumiał w charakterystyczny dla siebie sposób.

W drugiej kolejności głos zabrał mgr Tomasz Chmielik z Uniwersytetu Marii Curie-Skłodowskiej w Lublinie, wygłaszając referat Polityka a globalizacja w myśli naukowej Zygmunta Baumana. Referent przybliżył główne tezy socjologa i filozofa odnośnie do procesu erozji państwa narodowego, postępującej równolegle do procesów globalizacji. Odniósł się również do wpływu tego typu zjawisk na politykę.

Trzecim referentem był Dominik Wysocki, magistrant z Uniwersytetu Adama Mickiewicza w Poznaniu. W swoim wystąpieniu zatytułowanym Czy polityka jest etyczna? Rozważania nad aktualnościa myśli filozoficznej Niccolo Machiavellego wskazał na klasyczne rozumienie polityki, ocenianej przez pryzmat skuteczności. Prelegent dokonał zestawienia założeń polityki rozumianej w sposób machiavellistyczny z praktyką polityczną, wskazując w szczególności na politykę zagraniczną Stanów Zjednoczonych oraz charakter rywalizacji międzypartyjnej w Rzeczypospolitej Polskiej.

Jako ostatni w tej części seminarium głos zabrali Julia i Remigiusz Chęcińscy, magistranci z Uniwersytetu Adama Mickiewicza w Poznaniu. Celem ich wystąpienia było ukazanie relacji występujących pomiędzy polityką a demokracją bezpośrednią. Referenci zauważyli, że mogą być one rozpatrywane na różnych poziomach: doktrynalnym, terminologicznym, pojęciowym oraz na poziomie praktyki społecznej. Po zakończeniu referatu wszystkim prelegentom biorącym udział w części pierwszej zadawano pytania, w dalszej kolejności nastąpiła dyskusja. 
Jako pierwszy w ramach sekcji drugiej (związanej z funkcjonowaniem partii politycznych) głos zabrał dr Michał Pienias z Uniwersytetu Łódzkiego. Wygłosił referat pod tytułem Kształtowanie się tożsamości programowej europejskiej socjaldemokracji na przykładzie analizy programów wyborczych Partii Europejskich Socjalistów z 2004 i 2009 r. Doktor M. Pienias w wystąpieniu przybliżył teorię wartości postmaterialnych R. Ingleharta i jej wpływ na tożsamość programową socjaldemokracji. Przy wykorzystaniu metod ilościowych wskazał na wyniki porównań programów politycznych PES w kolejnych wyborach do Parlamentu Europejskiego w 2004 i 2009 r. Wnioskując prelegent dowodził, że równość jako idea przewodnia lewicy w Europie straciła na znaczeniu pod koniec lat dziewięćdziesiątych. Socjaldemokracja europejska skoncentrowała się na równości wobec prawa, równości płci, równości politycznej, natomiast zaniedbano równość w sensie socjalnym.

Drugie wystąpienie w ramach tej sekcji zatytułowane Zasadnicze kierunki polityki gospodarczej w programach Unii Demokratycznej, Unii Wolności i Partii Demokratycznej demokraci.pl wygłosił dr Dominik Szczepański z Uniwersytetu Rzeszowskiego. Doktor w zwięzły sposób przedstawił główne tezy programowe pojawiające się w programach wymienionych ugrupowań, wskazując jednocześnie na ich podobieństwa, różnice oraz ewolucję.

Trzeci referat zatytułowany Komunikowanie polityczne ludowców w Drugiej Rzeczypospolitej wygłosiła doktorantka mgr Agnieszka Strykowska z Uniwersytetu Marii Curie-Skłodowskiej w Lublinie. Celem wystąpienia było ukazanie możliwości zastosowania elementów teorii komunikowania społecznego do analizy komunikacji ugrupowań ludowych w okresie II RP. Wykorzystując teorię, autorka wskazała na autorów treści komunikacyjnych, stosowane przez nich formy i kanały przekazu oraz odbiorców komunikatów.

Czwarte wystąpienie zatytułowane Poglądy lewicy na państwo i politykę - rys historyczny wygłosił Tymoteusz Mądry, magistrant z Uniwersytetu Adama Mickiewicza w Poznaniu. Referent przedstawił lewicowe rozumienie istoty polityki. W swoim referacie w sposób przekrojowy ukazał ewolucję tego podejścia, począwszy od czasów Karola Marksa aż do współczesności. Po zakończeniu wystąpienia analogicznie do części pierwszej zadawano pytania i przeprowadzono dyskusję.

W ostatniej, trzeciej sekcji, dotyczącej zagadnień natury prawnej referowali w kolejności: dr Grzegorz Maroń z Uniwersytetu Rzeszowskiego oraz 
reprezentujący ten sam ośrodek dr Artur Łuszczyński. Doktor G. Maroń $\mathrm{w}$ referacie zatytułowanym Treści konfesyjne $w$ dyskursie polityczno-prawnym na przykładzie uchwał okolicznościowych Sejmu i Senatu RP analizował podejmowane przez obie izby parlamentu uchwały o treściach religijnych. Prelegent przedstawił własne spostrzeżenia na temat polityczności przyjmowanych uchwał oraz prognozy odnośnie ich znaczenia. Zauważył, że w obliczu procesów laicyzacji społeczeństwa należy przypuszczać, iż ten typ uchwał nieraz będzie stymulował polityczne spory.

Wystąpienie ostatniego z referentów, doktora Artura Łuszczyńskiego, zostało zatytułowane Prawo, polityka i ich filozofia, czyli o zasadności posługiwania się terminami względnie utrwalonymi. Doktor podjął problem zasadności definiowania pojęć tytułowych, wskazując na dwa skrajne podejścia. Z jednej strony niektórzy badacze w ślad za postulatem Karla Raimunda Poppera uznają spory definicyjne za nieistotne „zabawy” lingwistyczne, z drugiej przedstawiciele nauk społecznych argumentują, że posługiwanie się precyzyjnymi pojęciami jest niezbędne między innymi podczas tworzenia teorii. Prelegent opowiedział się za drugim z wymienionych rozwiązań.

Ostatnia część seminarium została podsumowana przez uczestników dyskusją nad pojawiającymi się w trakcie wygłaszania referatów wątpliwościami. Na zakończenie seminarium prowadząca dr Anna Pięta-Szawara podziękowała uczestnikom oraz słuchaczom za udział. Zachęciła jednocześnie zgromadzonych do wzięcia udziału w kolejnym seminarium z zainicjowanego cyklu, które zostanie poświęcone problematyce partii politycznych.

Przemysław Maj Uniwersytet Rzeszowski 